\author{
A. F. Guseva, M. V. Trifonova \\ Ural Federal University \\ 620000, Ekaterinburg, Mira 19, tel:+79126373816 \\ E-mail:anna.guseva@urfu.
}

\title{
Surface reactions with participation of oxides of molybdenum and tungsten
}

The kinetics of surface reactions in one-dimensional and radial (two-dimensional) distribution of diffusant $\mathrm{MoO}_{3}\left(\mathrm{WO}_{3}\right)$ on the surface of the substrate $\mathrm{MeO}$ ( $\mathrm{Me}$ is $\mathrm{Cd}$, $\mathrm{Ni}, \mathrm{Pb}, \mathrm{Mn}, \mathrm{Cu}$ ) were investigated. A kinetic equation satisfactorily describes the rate of surface reactions in the case of radial distribution of diffusant on the substrate. It's found that when the radial distribution of diffusant the growth of layer on the substrate surface eventually slows down and stops almost completely, due to the outflow of the diffusant deeps into the substrate. When the one-dimensional distribution of diffusant the surface interaction is not slowed down and does not stop at an arbitrarily large times.

Keywords: diffusant; molybdates; complex oxides; surface reaction diffusion; scanning electron microscopy (SEM)

(C) Guseva A. F., Trifonova M. V., 2015

\section{Introduction}

The reaction diffusion in the synthesis of molybdates and tungstates, as well as many other complex oxides, includes bulk, grain-boundary and surface diffusion. The separation of these three streams and study of their mechanism is the most important task of the science of solid-phase reactions. In the synthesis of molybdates and tungstates the formation of the reaction product is found not only in the place of contact of the pellets of the reactants, but also outside it, on the surface of one of the reagents (substrate). This indicates a large contribution of surface reaction diffusion (SRD) in a total reaction transfer and provides a unique opportunity to select and research one of three major streams of the reaction mass.

One of the quantitative characteristics of the SRD is the ratio of the length of the surface layer $\left(\ell_{s}\right)$ to the thickness of the layer of product at the place of contact of reagents $(\ell)$. The value of $\ell_{s} / \ell$ for the same diffusants $\mathrm{MoO}_{3}\left(\mathrm{WO}_{3}\right)$ varies in very wide limits from $\ell_{\mathrm{s}} / \ell \approx 1 \ldots 180$.

In papers [1-3] more than 20 surface reactions with the participation of $\mathrm{MoO}_{3}$ $\left(\mathrm{WO}_{3}\right)$ were studied and the following basic facts were installed:

1. A sharp slowdown in surface reactions, up to a full stop, after reaching a certain value of the length of the surface layer. 
2. The independence of the maximum length of the surface layer $\ell_{s}^{\max }$ from the temperature of the experiment; with changes in temperature, only the time to reach $\ell_{s}^{\max }$ changes.

3. The dependence of the rate of surface reactions on porosity of the substrate, which is localized on the surface layer. With increasing porosity $\ell_{s}$ decreases sharply.

4. The high sensitivity of the speed of SRD to the influence of an electric field; a complex nonmonotonic dependencies $\ell_{s}$ $(U)$ are observed.

5. The speed of surface reactions is significantly higher for those reaction pairs where the product of the interaction contains several phases.

Thus, the effect of SRD has been studied well enough. However, the authors [1-3] noted that a number of experimental facts obtained in the study of this phenomenon (for example, termination of surface interaction when reaching a certain value of the length of the surface layer) can not be explained. Further, up

\section{The experimental part}

We used $\mathrm{NiO}, \mathrm{CuO}, \mathrm{MoO}_{3}, \mathrm{WO}_{3}$, $\mathrm{PbO}, \mathrm{Mn}_{2} \mathrm{O}_{3}, \mathrm{CdO}$ (qualification "h.p."). $\mathrm{Pb}_{2} \mathrm{MoO}_{5}$ was synthesized from simple oxides by standard ceramic technique in three stages with intermediate milling at temperatures of $550-750{ }^{\circ} \mathrm{C}$; time of annealing at each stage was 15 hours. The phase composition was controlled by $\mathrm{x}$ ray. The samples for investigation were prepared in the form of briquettes by pressing and subsequent sintering. The sintering conditions of the samples are given in table 1.

The surface diffusion of the reaction was studied in one-dimensional and two- to the present time the research was conducted for this cell geometry, in which the proliferation of diffusant, and, consequently, the growth of the surface layer occurs radially with respect to the place of contact of the reactants. In this case, the diffusion is two-dimensional. At the same time, kinetic dependencies, linking some characteristic speed of the process over time, are obtained for one-dimensional diffusion. In connection with the foregoing, in the present work the following objectives are stated:

1) To obtain the growth equation of the surface layer in the radial distribution of diffusant, which satisfactorily describes the kinetics of surface interactions.

2) To investigate the kinetics of surface interactions in the case of one-dimensional distribution of diffusing into the systems $\mathrm{CuO}-\mathrm{MoO}_{3}, \mathrm{Mn}_{2} \mathrm{O}_{3}-\mathrm{MoO}_{3}, \mathrm{NiO}-$ $\mathrm{MoO}_{3}, \mathrm{NiO}-\mathrm{WO}_{3}, \mathrm{PbO}-\mathrm{MoO}_{3}$.

3) Using scanning electron microscopy (SEM) to study the morphology of the reaction product on the surface and at the site of contact of the reactants.

dimensional distribution of diffusant. For this purpose we used cells with different geometry of the assembly of briquettes reagents. In one case, the disc diameter of the substrate briquette was $15 \mathrm{~mm}$, and the diameter of the disc diffusant $-5 \mathrm{~mm}$ (fig. 1a); in another case substrate had a shape of a bar with a height of 5-10 mm and an area of contact with the surface diffusant $65-75 \mathrm{~mm}^{2}$, and the sample diffusant was made in the form of a disk with a diameter of $15 \mathrm{~mm}$ and a thickness of $2 \mathrm{~mm}$ (fig. 1b). The distribution scheme of diffusant on the substrate is shown by arrows. 
Table 1

The sintering conditions of the samples

\begin{tabular}{c|c|c} 
Compound & $\begin{array}{c}\text { Annealing } \\
\text { temperature, }{ }^{\circ} \mathrm{C}\end{array}$ & $\begin{array}{c}\text { Annealing } \\
\text { time, hour }\end{array}$ \\
\hline $\mathrm{NiO}$ & 1200 & 6 \\
\hline $\mathrm{Mn}_{2} \mathrm{O}_{3}$ & 900 & 24 \\
\hline $\mathrm{Pb}_{2} \mathrm{MoO}_{5}$ & 700 & 48 \\
\hline $\mathrm{PbO}$ & 760 & 24 \\
\hline $\mathrm{CuO}$ & 950 & 18 \\
\hline $\mathrm{CdO}$ & 700 & 24 \\
\hline $\mathrm{MoO}_{3}$ & 600 & 3 \\
\hline $\mathrm{WO}_{3}$ & 900 & 3
\end{tabular}

Overseeing the development process was carried out by periodic measurement of the length of the surface layer $\ell_{s}$, layer $\ell$, formed in the contact area of the briquettes, the weight of the substrate.

$\mathrm{X}$-ray analysis of objects of research was carried out on diffractometer DRF2.0 in the $\mathrm{Co}_{\mathrm{K \alpha}}$ radiation. The survey was conducted at a speed of $2{ }^{\circ} \mathrm{C} / \mathrm{min}$ in the range of angles $2 \theta$ from 5 to $35^{\circ} \mathrm{C}$. The interpretation of radiographs was carried out using the card file ASTM.

The microscopic analysis of the surface and chipping of the pellets after annealing was performed using microscope MBS-9 with magnification 16 to 56 times
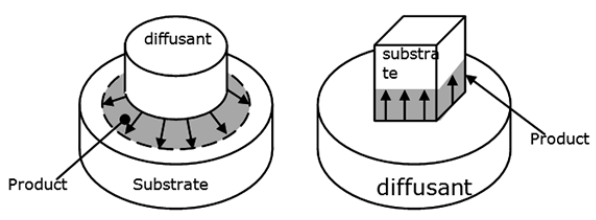

Fig. 1. The scheme of experiments for the investigation of kinetics of surface interactions: $a$ - radial distribution of diffusant; $b$-one-dimensional distribution of diffusant.

and optical microscope POLAM S-112 in transmitted light at magnification of 300-420 time.

The morphology of the substrate and product, as well as their elemental composition, was investigated using the electron microscope JSM-3 with a microprobe at magnification of 300-3000 times.

The measurement of the mass of briquettes before and after diffusion annealing was carried out on an analytical balance Sartorius - BL60S with an accuracy of $0.0001 \mathrm{~g}$.

The effective density of samples was determined by the volume and mass of samples and hydrostatic weighing. Its value variated from 60 to $85 \%$.

\section{Results and discussion}

The kinetic growth equation of the surface layer in the radial diffusion

As shown earlier [1-3], one interesting feature of the SRD is an atypical form of the kinetic dependences, which have the form of curves with saturation. When analyzing this phenomenon, we drew attention to the fact that a complete shutdown of surface interaction is recorded by conducting experiments for cells with such a geometry assembly of briquettes of rea- gents, which was radial (two-dimensional) distribution of diffusant on the surface of the substrate (fig. 1, a).

It are obvious that the classical limit cases for the kinetic and diffusion regimes $\left(\ell=K \tau\right.$ and $\left.\ell^{2}=K \tau\right)$ is not consistent in the description of the kinetics of radial diffusion. When the radial distribution of diffusant, unlike the one-dimensional case, there is a constant increase in the length of the reaction front, which should 
lead to change of time dependence of the parameter characterizing the rate of reaction $\left(\ell_{s}\right)$. Therefore, in this work the task was to obtain a growth equation of the surface layer in the radial distribution of diffusant on the substrate surface.

The derivation of the equation was not taken into account the outflow of diffusant deep into the substrate, i.e. the case of surface reaction diffusion was considered in pure form.

According to the general principles of thermodynamics of nonequilibrium processes the speed of any non-equilibrium process (including chemical reactions) is proportional to some "driving force" of the process and is inversely proportional to a certain effective value of $R^{\star}$ which is the resistance process [4]. The thermodynamic driving force of chemical interaction is the difference in isobaricisothermal potentials of the reaction $\Delta \mathrm{G}$. Then the reaction rate of surface reaction is determined by the ratio:

$$
W=\frac{\Delta G}{R^{*}}
$$

On the other hand, the rate of surface reaction can be determined by the area change of a reaction product formed on the surface of the substrate, per unit time, fig. 2.

The rate of surface reaction is determined by varying the amount of reaction product formed on the surface, per unit time:

$$
W=\frac{d n_{\text {пов }}}{d \tau}
$$

The amount of the substance on the surface is proportional to its volume: $n_{\text {пов }}$ $\sim V_{\text {пов. }}$. In turn, the volume of the surface layer is equal to the mathematical product of its area by thickness: $V_{\text {пов }}=S_{\text {пов }} \cdot \delta$. As a first approximation we can assume that the thickness of the surface of the product $(\delta)$ is a constant value, since it is less on orders than the length of the surface layer; then the number of product on the surface is proportional to the occupied of the area: $n_{\text {пов }} \sim S_{\text {пов }}$, which suggests that the reaction rate is equal to the change of the square of the reaction product formed on the surface, per unit time:

$$
W=\frac{d S_{\text {пов }}}{d \tau} .
$$

The resistance of the solid-phase reaction is the sum of resistance of separate stages, the main of which are actually chemical interaction (resistance $R_{\text {chem }}$ ) and diffusion (resistance $R_{\mathrm{dif}}$ ):

$$
R^{*}=R_{\text {chem }}+R_{\text {dif }}
$$

Equating (1) and (3), we obtain:

$$
\frac{d S_{\text {пов }}}{d \tau}=\frac{\Delta G}{R_{\text {хим }}+R_{\text {диф }}} .
$$

The size of the surface layer is determined by the expression:

$$
S_{\text {пов }}=\pi\left(\left(r+\ell_{\mathrm{s}}\right)^{2}-r^{2}\right)=\pi \ell_{\mathrm{s}}\left(2 \mathrm{r}+\ell_{\mathrm{s}}\right) \text {, }
$$

where $r$ - the radius of the briquette diffusant.

It is obvious that the resistance of the chemical stage $R_{\text {chem }}$ is proportional to the length of the front surface reactions, i.e. the length of a circle of radius $\left(r+\ell_{\mathrm{s}}\right)$ :

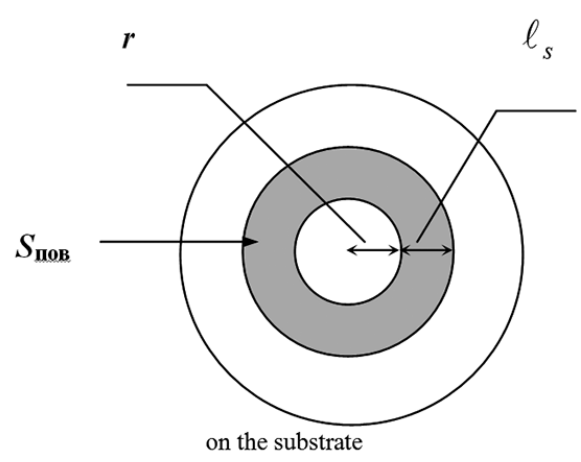

Fig.2. The lay ut of the surface layer (grey colour) on the substrate 


$$
R_{\text {chem }}=a \cdot 2 \pi\left(r+\ell_{\mathrm{s}}\right),
$$

where $a$ is a certain resistivity of the chemical stage, depending on the nature of the reacting substances. The resistance stage of diffusion is directly proportional to the length of the surface layer:

$$
R_{d i f}=b \cdot \ell_{s}
$$

where $b$ is the resistivity of the diffusion stage. Substituting (6), (7) and (8) into (5), we obtain the expression:

$$
\frac{d\left[\pi \ell_{s}\left(2 r+\ell_{s}\right)\right]}{d \tau}=\frac{\Delta G}{2 \pi a\left(r+\ell_{s}\right)},
$$

which is converted to

$$
2 \pi \frac{d \ell_{s}}{d \tau}\left(r+\ell_{s}\right)=\frac{\Delta G}{2 \pi a\left(r+\ell_{s}\right)+b \ell_{s}} .
$$

Separating variables and integrating (10), we obtain:

$4 \ell_{s} \pi^{2} a r^{2}+\ell_{s}^{2} \pi r(b+4 \pi a)+\frac{2}{3} \ell_{s}^{3} \pi(2 \pi a+b)=\Delta G \tau$

Denoting the constant as follows: $4 \pi^{2} a r^{2}=x ; \pi r(b+4 \pi a)=y ; 2 / 3 \pi(2 \pi a+b)=z$, and substituting in (11), we finally obtain:

$$
x \ell_{s}+y \ell_{s}^{2}+z \ell_{s}^{3}=\Delta G \tau
$$

Thus, the dependence of the length of the surface layer with time is described by a polynomial of the third degree.

The derivation of this equation is not stated which of the stages (diffusion or kinetic) limits the entire process. Let us now consider special cases.

Since and $R_{\text {chem }}$, and $R_{\text {dif }}$, according to the equations (7), (8), depend on the length of the surface layer, which increases with time, the resistance of chemical and diffusion stages also will be constantly expanding in the surface reaction. This means that in the case of two-dimensional (radial) diffusion at short times it cannot be neglected diffusion resistance, as in the

one-dimensional case. Then it is obvious that the mode of interaction will depend only on the resistivity which stage (diffusion or kinetic) is larger in magnitude.

\section{Kinetic mode.}

When kinetic control of the process the resistivity of the diffusion stage is significantly smaller than the stage of chemical interaction: $b<<$ a, hence $R_{d i f}<<R_{\text {chem }}$, that is the diffusion resistance can be neglected.

Then the expression (9) is converted to the following:

$$
\frac{d\left[\pi \ell_{s}\left(2 r+\ell_{s}\right)\right]}{d \tau}=\frac{\Delta G}{2 \pi a\left(r+\ell_{s}\right)} .
$$

Making a transformation similar to the above, we get:

$$
r^{2} \ell_{s}+r \ell_{s}^{2}+\frac{\ell_{s}^{3}}{3}=K_{\text {хим }} \tau,
$$

where $K_{\text {хим }}=\frac{\Delta G}{4 \pi^{2} a}$.

Thus, the dependence of the length of the surface layer from time to time in the case of kinetic control of the process is also described by a polynomial of the third degree.

B) Diffusion regime.

Under the diffusion control of process the resistivity of the diffusion stage is significantly greater than the stage of chemical interaction: $b>>a$, therefore $R_{d i f}$ $>R_{\text {chem }}$, that is, the resistance stage, the chemical interaction can be neglected. Then the expression (9) is converted to the following:

$$
\frac{d\left[\pi \ell_{s}\left(2 r+\ell_{s}\right)\right]}{d \tau}=\frac{\Delta G}{b \ell_{s}} .
$$

After transformations we get the equation: 


$$
r \frac{\ell_{s}^{2}}{2}+\frac{\ell_{s}^{3}}{3}=K_{\text {диф }} \tau,
$$

where $K_{\text {диф }}=\frac{\Delta G}{2 \pi b}$.

Thus, when the diffusion control of process the time dependence of the length of the surface layer is described by a thirdorder polynomial with a zero coefficient for the first member of $\left(\ell_{s}\right)$.

So, when the radial distribution of diffusant on the surface of the substrate the kind of dependence of the length of the surface layer with time is not fundamentally dependent on the interaction mode. In all cases the dependence $\ell_{\mathrm{s}}=f(\tau)$ is described by polynomial of third degree (12).

However, equation (12) does not prescribe a termination surface interaction at sufficiently large times, what was observed experimentally earlier [1-3] for more than a dozen systems studied, as well as in the present work. The reason for the stop of the surface interactions, probably is associated with the outflow of diffusant deep into the substrate that were not considered in the derivation of this equation.

The Investigation of kinetics of surface interaction for radial and one-dimensional distribution of diffusant

As noted previously, the study of the surface reaction diffusion in one-dimensional propagation of diffusant was conducted.

Therefore, in the present work we study the kinetics of surface reactions in the radial and one-dimensional distribution of diffusant (fig. 1) in comparison. The equations of the studied reactions are: $\mathrm{NiO}+\mathrm{WO}_{3} \rightarrow \mathrm{NiWO}_{4}\left(t=850^{\circ} \mathrm{C}\right)$

$\mathrm{NiO}+\mathrm{MoO}_{3} \mathrm{NiMoO}_{4} \rightarrow\left(t=550^{\circ} \mathrm{C}\right)$

$2 \mathrm{Mn}_{2} \mathrm{O}_{3}+4 \mathrm{MoO}_{3} \rightarrow 4 \mathrm{MnMo}+\mathrm{O}_{2}\left(t=600^{\circ} \mathrm{C}\right)(19)$

$$
\begin{aligned}
& \mathrm{CdO}+\mathrm{MoO}_{3} \rightarrow \mathrm{CdMoO}_{4}\left(t=550^{\circ} \mathrm{C}\right) \\
& \mathrm{Pb}_{2} \mathrm{MoO}_{5}+\mathrm{MoO}_{3} \rightarrow 2 \mathrm{PbMoO}_{4}\left(t=600^{\circ} \mathrm{C}\right) \\
& \mathrm{PbO}+\mathrm{MoO}_{3} \rightarrow \mathrm{PbMoO}_{4}\left(t=600^{\circ} \mathrm{C}\right)
\end{aligned}
$$

$$
\left(\mathrm{Pb}_{2} \mathrm{MoO}_{5}\right)
$$

The product $\mathrm{Pb}_{2} \mathrm{MoO}_{5}$ is in parentheses that can be formed according to the state diagram, but were not detected during this study by means of SRD.

The kinetic dependences of the length of the surface layer by one-dimensional and radial (two-dimensional) diffusion is presented in fig. 3.

From fig. 3 it can be seen that the form of the kinetic curves in one-dimensional and radial (two-dimensional) SRD is different.

In the case of two-dimensional diffusion the curves go out of the saturation quickly (10-20 hours). In order to verify the applicability in the previous section, equation (12) to the description of the kinetics of the SRD in the case of radial diffusion was carried out the processing of the experimental curves 2 (fig. 3) using equation (12), wherein the processing were taken as part of the curve (until saturation). The correlation coefficients are shown in table 2.

Table 2

\begin{tabular}{c|c}
\multicolumn{2}{c}{ Correlation coefficients } \\
System & $\begin{array}{c}\text { Correlation coefficients, } \\
\%\end{array}$ \\
\hline $\mathrm{PbO} / \mathrm{MoO}_{3}$ & 95 \\
\hline $\mathrm{Mn}_{2} \mathrm{O}_{3} / \mathrm{MoO}_{3}$ & 93 \\
\hline $\mathrm{NiO} / \mathrm{MoO}_{3}$ & 96 \\
\hline $\mathrm{NiO} / \mathrm{WO}_{3}$ & 92 \\
\hline $\mathrm{CdO} / \mathrm{MoO}_{3}$ & 97
\end{tabular}

High values of correlation coefficients (more than $90 \%$ ) show that the equation (12) satisfactorily describes the experimental kinetic data presented in terms of geometry for time that is less than the 

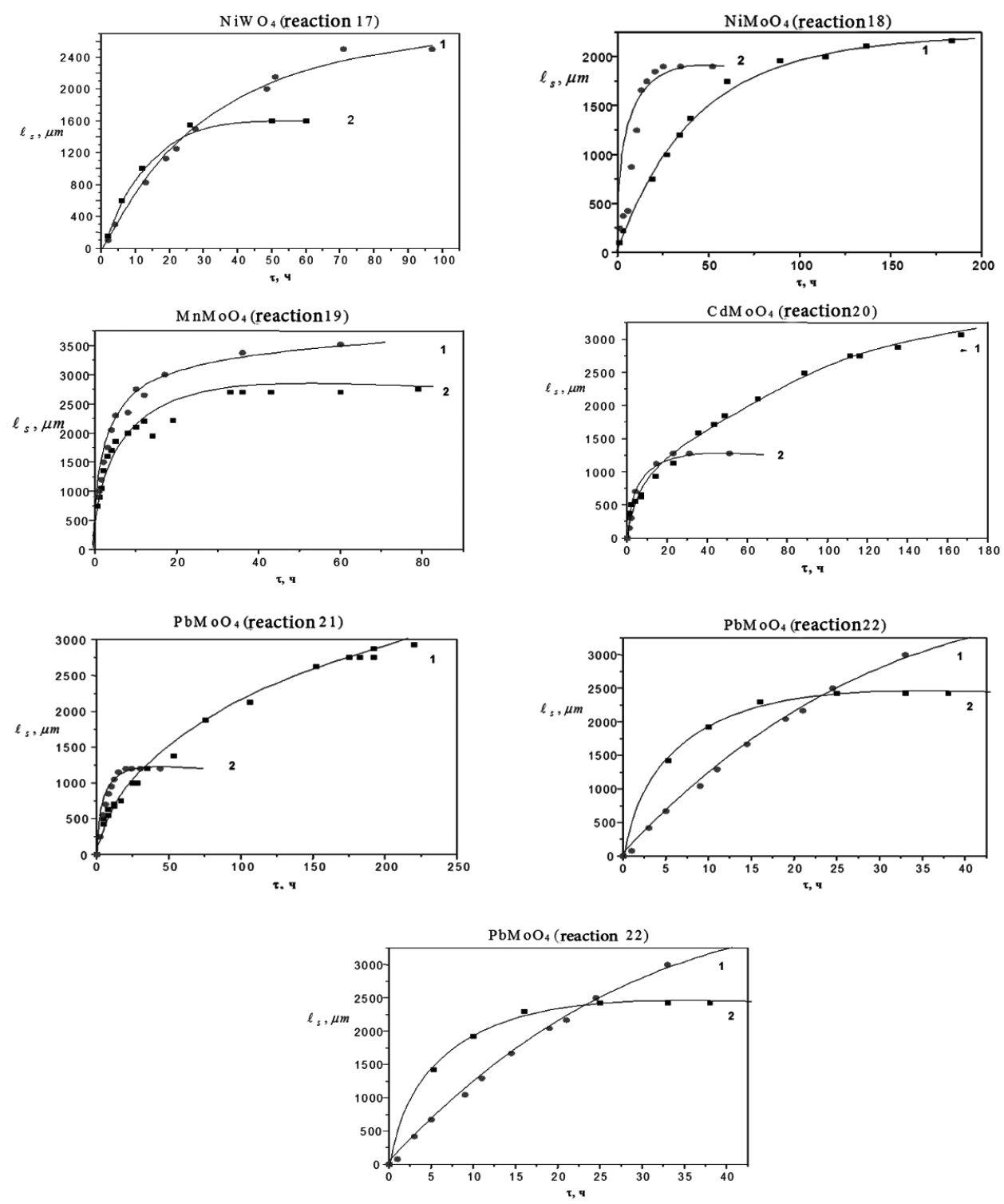

Fig.3. The dependence of the length of the surface layer from time to time: 1 - dimensional; 2 - radial (two-dimensional) distribution of diffusant

critical value $\tau_{\text {max }}$ at which the maximum value of the length of the surface layer is achieved.

When the one-dimensional distribution of diffusant during annealing over 70-100 hours the change in the length of the surface layer is still so that it is possi- ble only to ascertain the slowing down at large times, which is reflected in the flattening out of the curve.

At large times (over 100 hours) the boundary between the surface layer of the product and the substrate is very uneven and blurred, so it is very difficult to visu- 
ally determine the length of the surface layer. "Blurring" of boundaries, probably associated with the formation of product on the surface not only by surface reactions, but also by gaseous diffusion of $\mathrm{MoO}_{3}$. Therefore, the error in determining the length of the surface layer at large times increases.

Therefore, the error in determining the length of the surface layer at large times increases, and using only the method of optical microscopy, it is impossible definitely to determine whether full stop the surface process, or only a sharp slowdown. To solve this problem, we used scanning electron microscopy in combination with $\mathrm{x}$-ray microanalysis.

The value of length of the surface layer in the two-dimensional distribution is always lower than the value in the onedimensional distribution for the same experiment time.

The reason for this is the fact that when radial diffusion the constant increase is in the length of the three-phase boundary diffusant/substrate/product, which is carried on direct interaction. In the case of one-dimensional diffusion the length of this boundary is constant. That is, the difference of values for two types of geometries is not evidence of differences in the speeds of surface reactions, since in these two cases one- and two-dimensional diffusion is respectively. The relative area occupied by the surface layer (normalized to the contact area of the reactants) $S_{\text {пов }}$ / $S_{\text {конт }}$ is a more correct characterization of the speed of the process, in our opinion. This can be explained by the following considerations. The rate of surface reaction is determined by varying the amount of reaction product formed on the surface, per unit time:

$$
W=\frac{d S_{\text {пов }}}{d \tau}
$$

The amount of the substance on the surface is proportional to its volume: $n_{\text {пов }}$ $\sim V_{\text {sur }}$. In turn, the volume of the surface layer is equal to the product of its area by thickness: . $V_{\text {пов }}=S_{\text {пов }} \delta$. As a first approximation we can assume that the thickness of the surface of the product $(\delta)$ is a constant value, then the amount of surface product is proportional to the occupied area: $n_{\text {пов }} \sim S_{\text {пов }}$, which suggests that the reaction rate is equal to the change of the square of the reaction product formed on the surface, per unit time:

$$
W=\frac{d S_{\text {пов }}}{d \tau} .
$$

In the case of one-dimensional and two-dimensional diffusion the square of the surface layer in different ways depend on $\ell_{s}$. When radial diffusion area of the surface layer is determined by the expression:

$$
S_{\text {пов }}=\pi\left(\left(r+\ell_{s}\right)^{2}-r^{2}\right)=\pi \ell_{s}\left(2 r+\ell_{s}\right),
$$
when one-dimensional diffusion is:

$$
S_{\text {пов }}=\ell_{\mathrm{s}} \cdot 2(a+b) \text {, }
$$

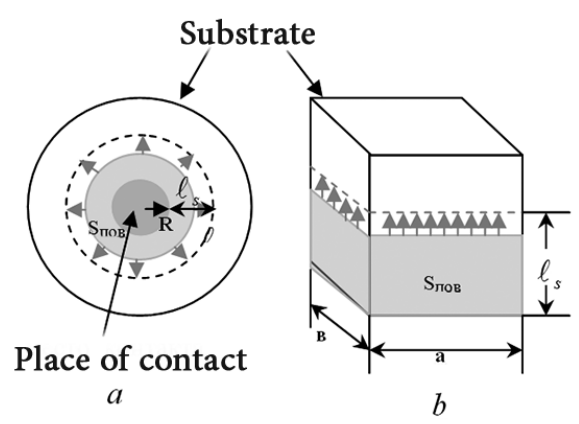

Fig. 4 . The scheme of change of the surface area of the reaction product: $a$-radial (twodimensional) disttribution of diffusant; $b$ - dimensional distribution of diffusant 
where $a$ and $b$ are the length and width of the briquette of the substrate, Fig.4.

The area of the surface layer depends on the diffusant contact area and the substrate, so it is better to compare not the length, and even not size, and the relative area of the surface layer (i. e., the ratio of the area of the surface layer to the contact area of the reactants). The contact area of the reactants are equal $S_{\text {пов }}=a \cdot b$, where a and $b$ are the sides of the base substrate in the case of one-dimensional diffusion and $S_{\text {конт }}=2 \pi r^{2}$, where $r$ is the radius of diffusant, in the case of radial diffusion.

The justice above considerations shows given as an example of the time dependence $S_{\text {пов }} / S_{\text {конт }}$ for one-dimensional and two-dimensional diffusion in the system $\mathrm{Mn}_{2} \mathrm{O}_{3}-\mathrm{MoO}_{3}$, fig. 5 .

Fig. 5 shows that the kinetic dependence $S_{\text {пов }} / S_{\text {конт }}$ for one-dimensional and two-dimensional distribution of diffusant are close.

Thus, the relative area of the surface layer is a more correct characteristic of the speed of surface reactions: under the radial distribution the diffusant tends to spread out over the surface of the substrate, forming a layer of a shorter length,

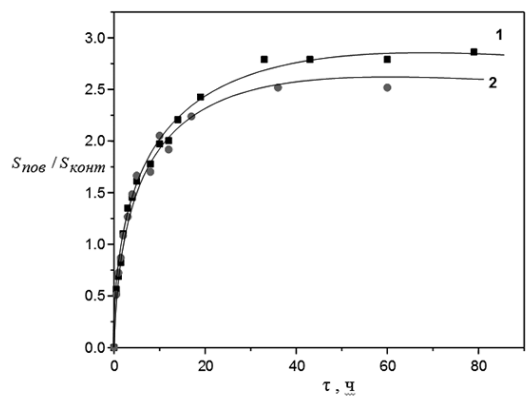

Fig. 5. The dependence of the relative area surface layer to the time the system $\mathrm{Mn}_{2} \mathrm{O}_{3}$ -

$\mathrm{MoO}_{3}: 1$ - dimensional, 2 - radial

(two-dimensional) diffusion but approximately the same area as that for one-dimensional diffusion.

To determine the mode of interaction the processing of the kinetic curves was carried out for the case of one-dimensional diffusion equation:

$$
\ell^{n}=K \tau \text {. }
$$

The values of the coefficient $n$ in equation (27) for the studied systems are shown in table 3.

Table 3

The values of the coefficient $n$ in equation $\ell^{n}=K \tau$

\begin{tabular}{c|c} 
System & coefficient $\mathrm{n}$ \\
\hline $\mathrm{CdO} / \mathrm{MoO}_{3}$ & $1.94 \pm 0.1$ \\
\hline $\mathrm{NiO} / \mathrm{WO}_{3}$ & $1.8 \pm 0.1$ \\
\hline $\mathrm{NiO} / \mathrm{MoO}_{3}$ & $1.9 \pm 0.1$ \\
\hline $\mathrm{Mn}_{2} \mathrm{O}_{3} / \mathrm{MoO}_{3}$ & $2 \pm 0.1$ \\
\hline $\mathrm{Pb}_{2} \mathrm{MoO}_{5} / \mathrm{MoO}_{3}$ & $2 \pm 0.1$
\end{tabular}

The coefficient $n$ for all systems is close to 2 , therefore, the surface reactions occur in the diffusion mode.

The study of the morphology of the surface layer by electron microscopy

The morphology of the substrate and the layer of product formed as a result of surface reaction diffusion (one-dimensional and two-dimensional) was investigated by electron microscopy with the aim to clarify the following points. First, is it possible to stop the SRD when onedimensional diffusion, or diffusion on the substrate surface does not stop until the source diffusion is not exhausted. For this purpose, in addition to REM, also x-ray microanalysis of sample was conducted.

Secondly, does the morphology of the product layer at the site of contact of the pellets of the reactants differ on the morphology of the surface layer?

REM-studies were conducted for six systems: $\mathrm{CdO}-\mathrm{MoO}_{3}, \mathrm{CuO}-\mathrm{MoO}_{3}, \mathrm{PbO}-$ 


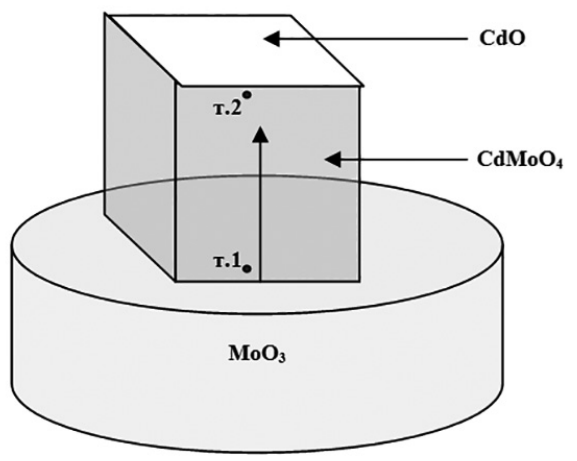

Fig.6. Scheme of direction SEM-photography of the sample

$\mathrm{MoO}_{3}, \mathrm{NiO}-\mathrm{MoO}_{3}, \mathrm{NiO}-\mathrm{WO}_{3}, \mathrm{Mn}_{2} \mathrm{O}_{3}-$ $\mathrm{MoO}_{3}$. As an example, the results of REM studies of one-dimensional diffusion in the system $\mathrm{CdO}-\mathrm{MoO}_{3}$ and radial (twodimensional) diffusion in the system $\mathrm{NiO}-\mathrm{MoO}_{3}$ are given.

\section{The System $\mathrm{CdO}-\mathrm{MoO}_{3}$}

The sample for the survey was obtained by means of contact diffusion couple annealing the pellets at the propagation of one-dimensional diffusing into the for 167 hours at a temperature of $550{ }^{\circ} \mathrm{C}$. Shooting direction is shown by the arrow from point 1 to point 2, Fig. 6 .

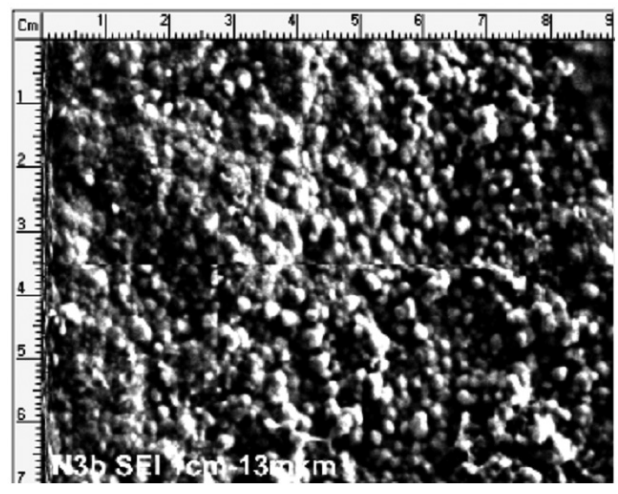

a
REM-images of the product $\mathrm{CdMoO}_{4}$ in point 1 and 2 (Fig. 6) are shown in Fig. $7 \mathrm{a}, \mathrm{b}$. The grain product have an average size of 4-5 $\mu \mathrm{m}$ (Fig. 7a). When moving off from the contact points, the layer acquires a loose structure, sometimes peels off from the substrate (Fig. 7 b).

In place of the detachment of the product the fine grains of the substrate $\mathrm{CdO}$ size $1-2 \mu \mathrm{m}$ are visible. Product $\mathrm{CdMoO}_{4}$ completely covers the substrate $\mathrm{CdO}$, as evidenced by both REM-images and $\mathrm{x}$-ray microanalysis data, which show the presence of molybdenum on the entire surface of the sample (Fig. 8).

Thus the conclusion made earlier is confirmed that in one-dimensional propagation of diffusant the growth of the surface layer does not stop at an arbitrarily large times, until the source diffusion is exhausted.

\section{The System NiO- $\mathrm{MoO}_{3}$}

The sample for the survey was obtained by means of contact diffusion couple annealing the pellets at the radial distribution of diffusant into the 4 hours at a temperature of $600{ }^{\circ} \mathrm{C}$.

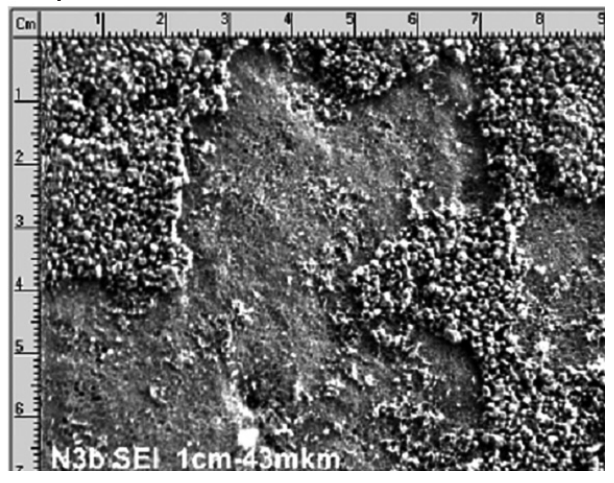

\section{$b$}

Fig.7. The PEM image of the surface layer of the product $\mathrm{CdMoO}_{4}$ on the substrate $\mathrm{CdO}$ : $a$-in point $1, \times 1000 ; b$-in point $2, \times 300$ (Fig. 6 ). 
The shooting direction is shown by the arrow (Fig. 9).

Analysis of REM-images shows that the grain size of the product $\mathrm{NiMoO}_{4}$ is approximately the same at all points of the sample and 1-2 $\mu \mathrm{m}$, fig. 10.

As mentioned earlier, it is impossible to determine the length of the surface layer by the method of optical microscopy. For more accurate determination by $\mathrm{x}$-ray microanalysis the concentration profile [Mo] and [Ni] was withdrawn, fig. 11.

The graph shows that the concentration of Moin placeof the contact of thebriquettes of diffusant/substrate is high and constant

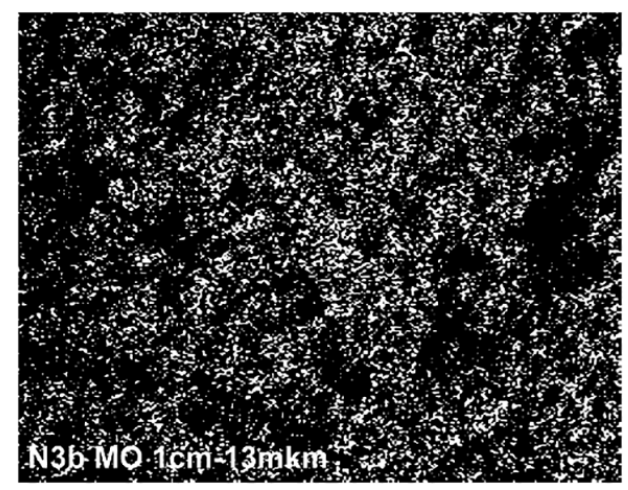

Fig. 8. The distribution of x-ray density of molybdenum on the surface of the substrate at a distance of $4.5 \mathrm{~cm}$ from the contact

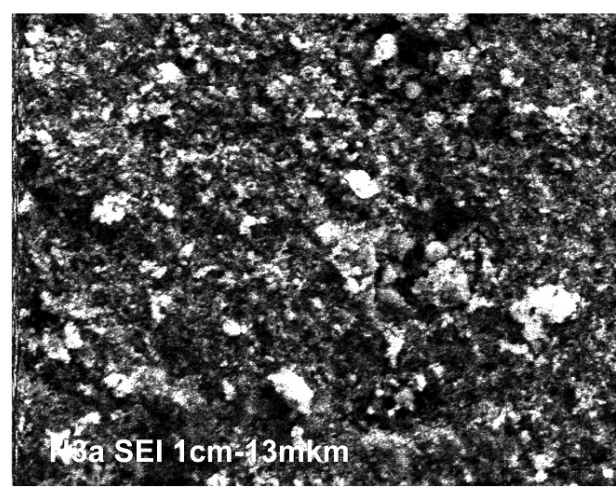

Fig. 10. The PEM image of the surface layer of the product $\mathrm{NiMoO}_{4}$ on size then as the distance from the contact is sharply reduced. This is due to the radial spread of diffusant on the surface of the substrate wherein the length of the reaction boundary is constantly growing whereby the front edge of the diffusion formation of a continuous layer of a product is not happended the product grains are alternated with the grains substrate, which physically corresponds to the descending order of the concentration of molybdenum as diffusant. Product grains are alternated with the substrate, which physically corresponds to the descending order of the concentration of molybdenum as diffusant.

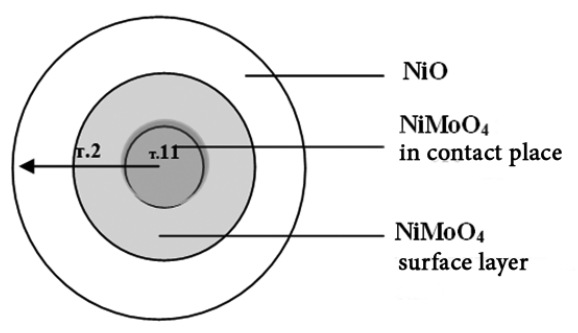

Fig. 9. Scheme of direction SEM-photography of the sample

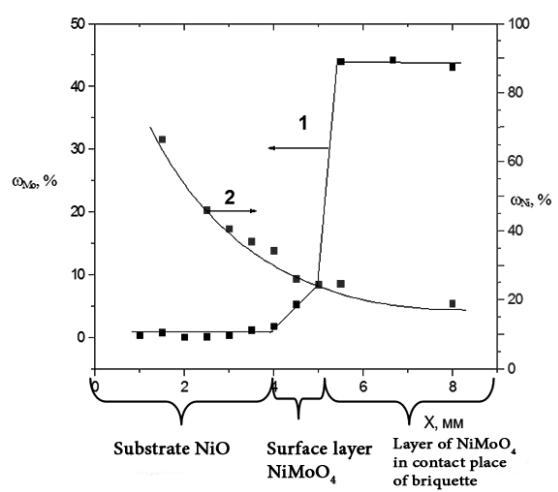

Fig. 11. Concentration profile (1) Mo; (2) Ni in the $\mathrm{NiO}$ sample with a layer of $\mathrm{NiMoO}_{4}$ (x-ray microanalysis data) 
The spot on the sample, where the fixed sharp decrease in the concentration of molybdenum is fixed, coincides with the length of the surface layer, determined by optical microscopy $(1200 \mu \mathrm{m})$.

Similar results are obtained for the other investigated systems.

\section{Conclusions}

The results of this work we can draw the following conclusions:

1 . The resulting equation of growth of the surface layer in the radial distribution of diffusant satisfactorily describes the kinetics of surface interactions at times that are lower than the terminating surface reactions.

2. The kinetics of surface interactions in the case of one-dimensional distribution of diffusant is investigated. It is established that surface reactions occur in the diffusion mode and unlike radial diffusion surface interaction does not stop even at large times.
3. It is found that the length of the surface layer in one-dimensional diffusion is greater than when radial and the relative area occupied by the surface product is almost the same in both cases. The latter testifies to the same speed of surface reactions in the radial and one-dimensional distribution of diffusant.

4. The morphology of the substrate surface layer and the morphology of the product formed at the site of contact of the briquettes was investigated. It is established that the surface layer on the front lines of reaction diffusion is not continuous but consists of individual grains.

1. Neiman A. Ya., Guseva A. F. New Data on the Mechanism of Mass Transfer in SolidPhase Reactions: II. Chemical and Electrochemical Surface Phenomena. Kinetics and Catalysis. 1999;40(I):38-49.

2. Neiman A. Ya., Guseva A. F., Trifonova M. V. Surface Reaction in the course of molibdates and tungstates formation. Solid State Ionics. 2001;141-142:321-329.

3. Neiman A. Ya., Guseva A. F., Trifonova M. V., Sukhankina I. V. Reactive Surface Diffusion durin Synthesis of Molybdates and Tungstates: The Role of Phase Constitution of Product. Russian Journal of Inorganic Chemistry. 2005;50:319-324.

4. Chebotin V. N., Perphiluev M. V. Electrochemistry of Solyd Electrolytes. Khimiya. Moscow, 1978. P. 67. (in Russian). 


\section{А. Ф. Гусева, М. В. Трифонова \\ Уральский федеральный университет, 620000, г. Екатеринбург, пр. Мира 19, тел.+7 (912) 637-38-16 E-mail:anna.guseva@urfu.ru}

\section{Поверхностные реакции с участием оксидов молибдена и вольфрама}

Исследована кинетика поверхностных реакций при одномерном и радиальном (двумерном) распространении диффузанта $\mathrm{MoO}_{3}\left(\mathrm{WO}_{3}\right)$ по поверхности подложки $\mathrm{MeO}$ ( $\mathrm{Me}-\mathrm{Cd}, \mathrm{Ni}, \mathrm{Pb}, \mathrm{Mn}, \mathrm{Cu}$ ). Предложено кинетическое уравнение, удовлетворительно описывающее скорость поверхностных реакций в случае радиального распространения диффузанта по подложке. Установлено, что при радиальном распространении диффузанта рост слоя на поверхности подложки со временем замедляется и практически полностью прекращается, что связано с оттоком диффузанта вглубь подложки. При одномерном распространении диффузанта поверхностное взаимодействие не замедляется и не прекращается при сколь угодно больших временах.

Ключевые слова: диффузант; молибдаты; сложные оксиды; поверхностная реакционная диффузия.

(C) Гусева А. Ф., Трифонова М. В., 2015

\section{Введение}

Реакционная диффузия при синтезе молибдатов и вольфраматов, как и многих других сложных оксидов, включает объемный, зернограничный и поверхностный массоперенос. Разделение этих трех потоков и изучение их механизма является важнейшей задачей науки о твердофазных реакциях. При синтезе молибдатов и вольфраматов обнаружено образование продукта реакции не только в месте непосредственного контакта брикетов реагентов, но и вне его, на поверхности одного из реагентов (подложки). Это свидетельствует о большом вкладе поверхностной реакционной диффузии (ПРД) в суммарный реакционный перенос и открывает уникальную возможность для выделения и исследования этого одного из трех важнейших потоков реакционного массопереноса.

Одной из количественных характеристик ПРД является отношение длины поверхностного слоя $\left(\ell_{s}\right)$ к толщине слоя продукта в месте контакта реагентов $(\ell)$. Величина $\ell_{s} / \ell$ для одних и тех же диффузантов $\mathrm{MoO}_{3}\left(\mathrm{WO}_{3}\right)$ варьируется в весьма широких пределах от $\ell_{s} / \ell \approx 1 \ldots 180$.

В работах [1-3] изучено более 20 поверхностных реакций с участием 
$\mathrm{MoO}_{3}\left(\mathrm{WO}_{3}\right)$ и установлены следующие основные факты:

1. Резкое замедление поверхностной реакции, вплоть до полной остановки, после достижении определенного значения длины поверхностного слоя.

2. Независимость значения максимальной длины поверхностного $\ell_{s}^{\max }$ слоя от температуры эксперимента; с изменением температуры меняется лишь время достижения $\ell_{s}^{\max }$.

3. Зависимость скорости поверхностной реакции от пористости подложки, на которой локализуется поверхностный слой. С ростом пористости $\ell_{s}$ резко уменьшается.

4. Высокая чувствительность скорости ПРД к воздействию электрического поля; сложный немонотонный характер зависимостей $\ell_{s}(U)$.

5. Скорость поверхностных реакций существенно выше для тех реакционных пар, в которых продукт взаимодействия содержит несколько фаз.

Таким образом, эффект ПРД достаточно хорошо исследован. Однако авторы [1-3] отмечают, что ряд экспериментальных фактов, полученных при исследовании этого явления (например, прекращение поверхностного взаимодействия при достижении определенного значения длины поверхностного слоя) не удается пока объяснить. Далее, до настоящего времени, проводились исследования для такой геометрии ячейки, при которой распространение диффузанта, а следовательно, рост поверхностного слоя происходит радиально по отношению к месту контакта реагентов. В этом случае диффузия происходит двумерно. В то же время кинетические зависимости, связывающие какую-либо характеристику скорости процесса со временем, получены для одномерной диффузии.

В связи с вышесказанным в настоящей работе поставлены следующие задачи:

1) Получить уравнение роста поверхностного слоя при радиальном распространении диффузанта, удовлетворительно описывающее кинетику поверхностного взаимодействия.

2) Исследовать кинетику поверхностного взаимодействия в случае одномерного распространения диффузанта в системах $\mathrm{CuO}-\mathrm{MoO}_{3}, \mathrm{Mn}_{2} \mathrm{O}_{3}$ $\mathrm{MoO}_{3}, \mathrm{NiO}-\mathrm{MoO}_{3}, \mathrm{NiO}-\mathrm{WO}_{3}$, $\mathrm{PbO}-$ $\mathrm{MoO}_{3}$.

3) Методом растровой электронной микроскопии исследовать морфологию продукта реакции на поверхности и в месте контакта реагентов.

\section{Экспериментальная часть}

В работе использовались $\mathrm{NiO}, \mathrm{CuO}$, $\mathrm{MoO}_{3}, \mathrm{WO}_{3}, \mathrm{PbO}, \mathrm{Mn}_{2} \mathrm{O}_{3}, \mathrm{CdO}$ (квалификации «ос.ч.»). $\mathrm{Pb}_{2} \mathrm{MoO}_{5}$ синтезировали из простых оксидов по стандартной керамической технологии в три стадии с промежуточными перетираниями при температурах 550$750{ }^{\circ} \mathrm{C}$; время отжига на каждой ста- дии составляло 15 ч. Фазовый состав контролировали рентгенографически. Образцы для исследования готовили в виде брикетов прессованием и последующим спеканием. Условия спекания образцов приведены в табл. 1.

Поверхностную реакционную диффузию изучали при одномерном и дву- 
мерном распространении диффузанта. Для этого использовали ячейки с разной геометрией сборки брикетов реагентов. В одном случае диаметр диска брикета подложки составлял 15 мм, а диаметр диска диффузанта - 5 мм (рис. $1, a)$; в другом подложка имела форму бруска высотой 5-10 мм и площадью контактирующей с диффузантом поверхности 65-75 мм², а образец диффузанта выполнялся в виде диска диаметром 15 мм и толщиной 2 мм (рис. 1, б). Схема распространения диффузанта по подложке показана стрелками.

Таблица 1

Условия спекания образцов

\begin{tabular}{c|c|c} 
Вещество & $\begin{array}{c}\text { Температура } \\
\text { отжига, }{ }^{\circ} \mathrm{C}\end{array}$ & $\begin{array}{c}\text { Время } \\
\text { отжига, ч }\end{array}$ \\
\hline $\mathrm{NiO}$ & 1200 & 6 \\
\hline $\mathrm{Mn}_{2} \mathrm{O}_{3}$ & 900 & 24 \\
\hline $\mathrm{Pb}_{2} \mathrm{MoO}_{5}$ & 700 & 48 \\
\hline $\mathrm{PbO}$ & 760 & 24 \\
\hline $\mathrm{CuO}$ & 950 & 18 \\
\hline $\mathrm{CdO}$ & 700 & 24 \\
\hline $\mathrm{MoO}_{3}$ & 600 & 3 \\
\hline $\mathrm{WO}_{3}$ & 900 & 3
\end{tabular}

Контроль за развитием процесса осуществлялся периодическим измерением длины поверхностного слоя $\ell_{\mathrm{s}}$, слоя $\ell$, образующегося в месте контакта брикетов, массы подложки.

Рентгенофазовый анализ объектов исследования выполняли на дифрактометре ДРФ-2.0 в $\mathrm{Co}_{\mathrm{K \alpha}}$ излучении. Съемку проводили со скоростью $2{ }^{\circ} \mathrm{C} /$ мин. в интервале углов 20 от 5 до
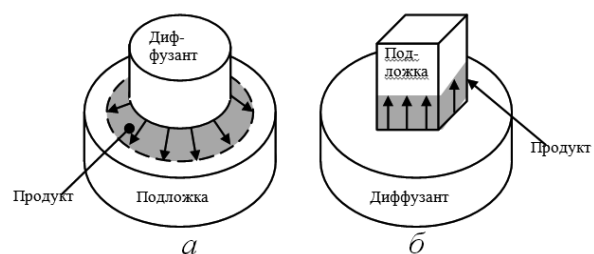

Рис. 1. Схема опытов по исследованию кинетики поверхностного взаимодействия: $a$ - радиальное распространение диффузанта; 6 одномерное распространение диффузанта

$35{ }^{\circ} \mathrm{C}$. Расшифровку рентгенограмм проводили с помощью картотеки ASTM.

Микроскопический анализ поверхности и сколов брикетов после отжигов проводили с помощью микроскопа МБС-9 при увеличении в 16-56 раз и оптического микроскопа ПОЛАМ C-112 в проходящем свете при увеличении в 300-420 раз.

Морфологию подложки и продукта, а также их элементный состав, исследовали с помощью электронного микроскопа JSM-3 с микроанализатором при увеличении 300-3000 раз.

Измерение массы брикеты до и после диффузионных отжигов проводили на аналитических весах Sartorius BL60S с точностью 0,0001 г.

Эффективную плотность образцов определяли по объему и массе образцов, а также методом гидростатического взвешивания. Ее величина варьировалась от 60 до $85 \%$.

\section{Результаты и обсуждение}

Кинетическое уравнение роста поверхностного слоя при радиальной диффузии

Как было показано ранее [1-3], одной из интересных особенностей ПРД является нетипичный вид кинетических зависимостей, которые име- 
ют вид кривых с насыщением. При анализе этого явления мы обратили внимание на то, что полную остановку поверхностного взаимодействия фиксировали, проводя эксперименты для ячеек с такой геометрией сборки брикетов реагентов, при которой происходило радиальное (двумерное) распространение диффузанта по поверхности подложки (рис. 1, a).

Очевидно, что классические предельные случаи для кинетического и диффузионного режимов $(\ell=K \tau)$ и $\left.\ell^{2}=K \tau\right)$ не состоятельны в описании кинетики радиальной диффузии. При радиальном распространении диффузанта, в отличие от одномерного случая, происходит постоянное увеличение длины реакционного фронта, что должно привести к изменению вида временной зависимости параметра, характеризующего скорость реакции $\left(\ell_{s}\right)$. Поэтому в настоящей работе была поставлена задача получить уравнение роста поверхностного слоя при радиальном распространении диффузанта по поверхности подложки.

При выводе уравнения не учитывался отток диффузанта вглубь подложки, т. е. рассматривался случай поверхностной реакционной диффузии в чистом виде.

Согласно общим принципам термодинамики неравновесных процессов скорость любого неравновесного процесса (в том числе и химической реакции) пропорциональна некоторой «движущей силе» процесса и обратно пропорциональна некоторой эффективной величине $R^{\star}$ - сопротивлению процесса [4]. Движущей термодинамической силой химического взаимодействия является разность изо- барно-изотермических потенциалов реакции $\Delta G$. Тогда скорость реакции поверхностной реакции определяется соотношением:

$$
W=\frac{\Delta G}{R^{*}}
$$

С другой стороны, скорость поверхностной реакции можно определить по изменению площади продукта ре-

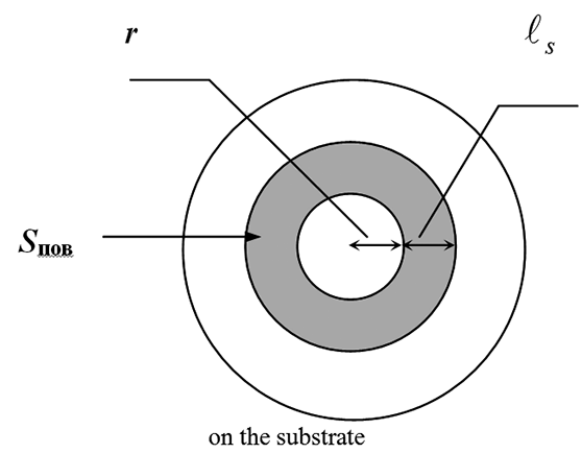

Рис. 2. Схема расположения поверхностного слоя (серый цвет) на подложке

акции, образующегося на поверхности подложки, в единицу времени, рис. 2.

Скорость поверхностной реакции определяется изменением количества продукта реакции, образующегося на поверхности, в единицу времени:

$$
W=\frac{d n_{\text {пов }}}{d \tau}
$$

Количество вещества на поверхности пропорционально его объему: $\quad n_{\text {пов }} \sim V_{\text {пов }}$ В $\mathrm{B}$ свою очередь, объем поверхностного слоя равен произведению его площади на толщину: $V_{\text {пов }}=S_{\text {пов }} \cdot \delta$. В первом приближении можно считать, что толщина поверхностного продукта ( $\delta)$ величина постоянная, так как она на порядки меньше длины поверхностного слоя; тогда количество продукта на повер- 
хности пропорционально занимаемой им площади: $n_{\text {пов }} \sim S_{\text {пов }}$, откуда следует, что скорость реакции равна изменению площади продукта реакции, образующегося на поверхности, в единицу времени:

$$
W=\frac{d S_{\text {пов }}}{d \tau} .
$$

Сопротивление твердофазной реакции складывается из сопротивления отдельных стадий, основными из которых являются собственно химическое взаимодействие (сопротивление $R_{\text {хим }}$ ) и диффузия (сопротивление $R_{\text {диф }}$ ):

$$
R^{*}=R_{\text {хим }}+R_{\text {диф }} \text {. }
$$

Приравняв (1) и (3), получим:

$$
\frac{d S_{\text {пов }}}{d \tau}=\frac{\Delta G}{R_{\text {хим }}+R_{\text {диф }}} .
$$

Площадь поверхностного слоя определяется выражением:

$$
S_{\text {пов }}=\pi\left(\left(r+\ell_{s}\right)^{2}-r^{2}\right)=\pi \ell_{s}\left(2 r+\ell_{s}\right),
$$

где $r$ - радиус брикета диффузанта.

Очевидно, что сопротивление химической стадии $R_{\text {хим }}$ пропорционально длине фронта поверхностной реакции, т. е. длине окружности радиусом $\left(r+\ell_{s}\right):$

$$
R_{\text {хим }}=a \cdot 2 \pi\left(r+\ell_{s}\right),
$$

где $a$ - некое удельное сопротивление химической стадии, зависящее от природы реагирующих веществ.

Сопротивление диффузионной стадии прямо пропорционально длине поверхностного слоя:

$$
R_{\text {диф }}=b \cdot \ell_{\text {s }}
$$

где $b$ - удельное сопротивление диффузионной стадии.

Подставив (6), (7) и (8) в (5), получим выражение:

$$
\frac{d\left[\pi \ell_{s}\left(2 r+\ell_{s}\right)\right]}{d \tau}=\frac{\Delta G}{2 \pi a\left(r+\ell_{s}\right)},
$$

которое преобразуем в

$$
2 \pi \frac{d \ell_{s}}{d \tau}\left(r+\ell_{s}\right)=\frac{\Delta G}{2 \pi a\left(r+\ell_{s}\right)+b \ell_{s}} .
$$

Разделив переменные и проинтегрировав (10), получим:

$$
4 \ell_{s} \pi^{2} a r^{2}+\ell_{s}^{2} \pi r(b+4 \pi a)+\frac{2}{3} \ell_{s}^{3} \pi(2 \pi a+b)=\Delta G \tau
$$

Обозначив постоянные следующим образом: $4 \pi^{2} a r^{2}=x ; \pi r(b+4 \pi a)=$ $y ; 2 / 3 \pi(2 \pi a+b)=z$, и, подставив в (11), окончательно получим:

$$
x \ell_{s}+y \ell_{s}^{2}+z \ell_{s}^{3}=\Delta G \tau
$$

Таким образом, зависимость длины поверхностного слоя от времени описывается полиномом третьей степени.

При выводе данного уравнения не конкретизировалось, какая из стадий (диффузионная или кинетическая) лимитирует весь процесс. Рассмотрим теперь частные случаи.

Так как и $R_{\text {хим }}$, и $R_{\text {диф }}$, согласно уравнениям (7), (8), зависят от длины поверхностного слоя, которая увеличивается во времени, то сопротивления химической и диффузионной стадий также будут постоянно расти в ходе поверхностной реакции. Это означает, что в случае двумерной (радиальной) диффузии при малых временах нельзя пренебречь диффузионным сопротивлением, как в одномерном случае. Тогда очевидно, что режим взаимодействия будет зависеть лишь от того, удельное сопротивление какой стадии (диффузионной или кинетической) больше по величине.

\section{А) Кинетический режим.}

При кинетическом контроле процесса удельное сопротивление диффузионной стадии значительно меньше, чем стадии химического взаимодейст- 
вия: $b<<a$, следовательно $R_{\text {диф }}<<R_{\text {хим' }}$ т. е. диффузионным сопротивлением можно пренебречь.

Тогда выражение (9) преобразуется в следующее:

$$
\frac{d\left[\pi \ell_{s}\left(2 r+\ell_{s}\right)\right]}{d \tau}=\frac{\Delta G}{2 \pi a\left(r+\ell_{s}\right)} .
$$

Сделав преобразования, аналогичные вышеизложенным, получим:

$$
r^{2} \ell_{s}+r \ell_{s}^{2}+\frac{\ell_{s}^{3}}{3}=K_{\text {хим }} \tau \text {, }
$$

где $K_{\text {хим }}=\frac{\Delta G}{4 \pi^{2} a}$.

Таким образом, зависимость длины поверхностного слоя от времени в случае кинетического контроля процесса также описывается полиномом третьей степени.

Б) Дифбфузионньй режим.

При диффузионном контроле процесса удельное сопротивление диффузионной стадии значительно больше, чем стадии химического взаимодействия: $b>>a$, следовательно $R_{\text {диф }}>>R_{\text {хим' }}$ т. е. сопротивлением стадии химического взаимодействия можно пренебречь.

Тогда выражение (9) преобразуется в следующее:

$$
\frac{d\left[\pi \ell_{s}\left(2 r+\ell_{s}\right)\right]}{d \tau}=\frac{\Delta G}{b \ell_{s}} .
$$

После преобразований получим уравнение:

$$
r \frac{\ell_{s}^{2}}{2}+\frac{\ell_{s}^{3}}{3}=K_{\text {диф }} \tau,
$$

где $K_{\text {диф }}=\frac{\Delta G}{2 \pi b}$.

Таким образом, и при диффузионном контроле процесса временная зависимость длины поверхностного слоя описывается полиномом третьей степени с нулевым коэффициентом при первом члене $\left(\ell_{s}\right)$.

Итак, при радиальном распространении диффузанта по поверхности подложки вид зависимости длины поверхностного слоя от времени принципиально не зависит от режима взаимодействия. Во всех случаях зависимость $\ell_{\mathrm{s}}=f(\tau)$ описывается полиномом третьей степени (12).

Однако уравнение (12) не предписывает прекращение поверхностного взаимодействия при достаточно больших временах, что наблюдали экспериментально ранее [1-3] более чем для десятка исследованных систем, а также в настоящей работе. Причина остановки поверхностного взаимодействия, вероятно, связана с оттоком диффузанта вглубь подложки, что не учитывалось при выводе настоящего уравнения.

Исследование кинетики поверхностного взаимодействия при радиальном и одномерном распространении диффузанта.

Как было отмечено, ранее исследование поверхностной реакционной диффузии при одномерном распространении диффузанта ранее не проводилось.

Поэтому в настоящей работе проведено исследование кинетики поверхностных реакций при радиальном и одномерном распространении диффузанта (рис. 1) в сравнении. Уравнения исследованных реакций:

$\mathrm{NiO}+\mathrm{WO}_{3} \rightarrow \mathrm{NiWO}_{4}\left(t=850^{\circ} \mathrm{C}\right)$

$\mathrm{NiO}+\mathrm{MoO}_{3} \mathrm{NiMoO}_{4} \rightarrow\left(t=550{ }^{\circ} \mathrm{C}\right)$

$2 \mathrm{Mn}_{2} \mathrm{O}_{3}+4 \mathrm{MoO}_{3} \rightarrow 4 \mathrm{MnMo}+\mathrm{O}_{2}\left(t=600^{\circ} \mathrm{C}\right)(19)$

$\mathrm{CdO}+\mathrm{MoO}_{3} \rightarrow \mathrm{CdMoO}_{4}\left(t=550^{\circ} \mathrm{C}\right)$

$\mathrm{Pb}_{2} \mathrm{MoO}_{5}+\mathrm{MoO}_{3} \rightarrow 2 \mathrm{PbMoO}_{4}\left(t=600^{\circ} \mathrm{C}\right)$ 
$\mathrm{PbO}+\mathrm{MoO}_{3} \rightarrow \mathrm{PbMoO}_{4}\left(t=600^{\circ} \mathrm{C}\right)$ $\left(\mathrm{Pb}_{2} \mathrm{MoO}_{5}\right)$

В скобках указан неосновной продукт $\mathrm{Pb}_{2} \mathrm{MoO}_{5}$, который может образовываться согласно диаграмме состояния, но не обнаружен при данном исследовании методом РФА.
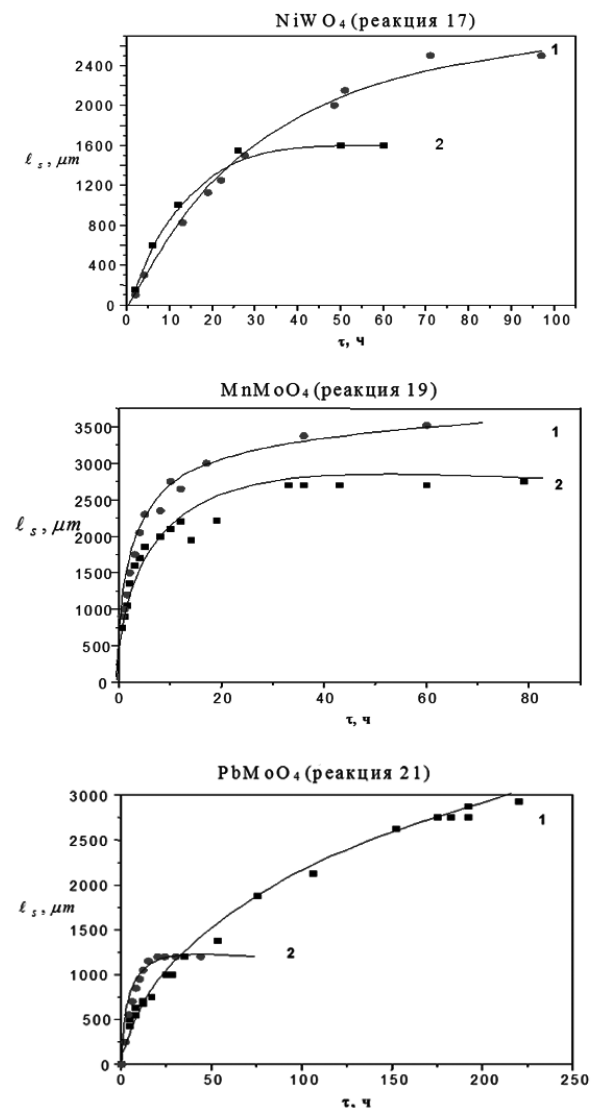

Кинетические зависимости длины поверхностного слоя от времени при одномерной и радиальной (двумерной) диффузии представлены на рис. 3.

На рис. 3 видно, что вид кинетических кривых при одномерной и ра-
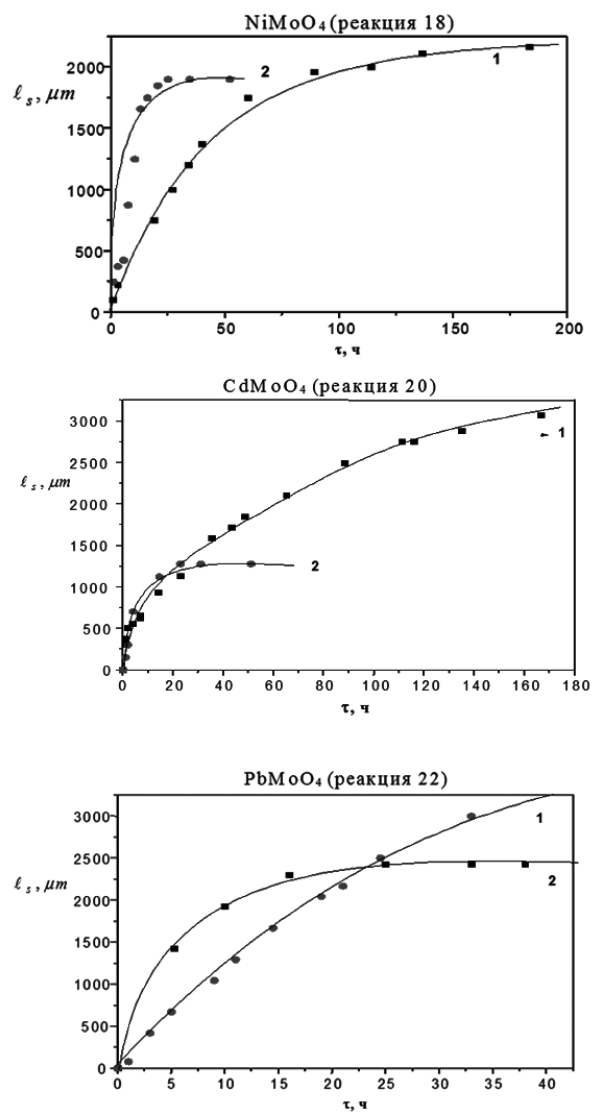

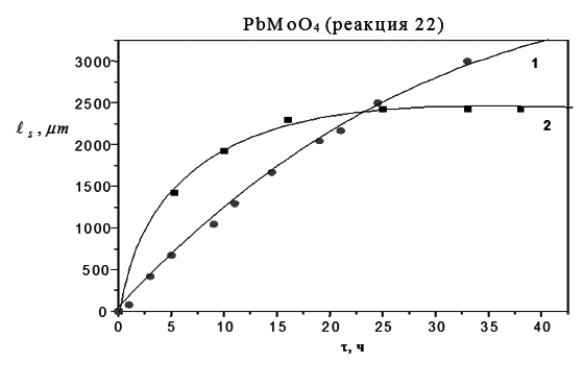

Рис. 3. Зависимость длины поверхностного слоя от времени:

1 - одномерное; 2 - радиальное (двумерное) распространение диффузанта 
диальной (двумерной) поверхностной диффузии различен.

В случае двумерной диффузии кривые быстро (в течение 10-20 ч) выходят на насыщение.

Для того чтобы убедиться в применимости полученного в предыдущем разделе уравнения (12) к описанию кинетики ПРД в случае радиальной диффузии, была проведена обработка экспериментальных кривых 2 (рис. 3) с помощью уравнения (12), причем для обработки были взяты части кривых (до насыщения). Коэффициенты корреляции приведены в табл. 2.

Таблица 2

Коэффициенты корреляции

\begin{tabular}{c|c} 
Система & $\begin{array}{c}\text { Коэффициенты } \\
\text { корреляции, \% }\end{array}$ \\
\hline $\mathrm{PbO} / \mathrm{MoO}_{3}$ & 95 \\
\hline $\mathrm{Mn}_{2} \mathrm{O}_{3} / \mathrm{MoO}_{3}$ & 93 \\
\hline $\mathrm{NiO} / \mathrm{MoO}_{3}$ & 96 \\
\hline $\mathrm{NiO} / \mathrm{WO}_{3}$ & 92 \\
\hline $\mathrm{CdO} / \mathrm{MoO}_{3}$ & 97
\end{tabular}

Высокие значения коэффициентов корреляции (более 90 \%) показывают, что уравнение (12) удовлетворительно описывает экспериментальные кинетические данные в условиях представленной геометрии для времени, меньшем критического значения $\tau_{\max }$, при котором достигается максимальное значение длины поверхностного слоя.

При одномерном распространении диффузанта при отжиге более 70-100 ч все еще происходит изменение длины поверхностного слоя, так что можно лишь констатировать замедление процесса при больших временах, что выражается в выполаживании кривой.

При больших временах (более 100 ч) граница между поверхностным слоем продукта и подложкой очень неровная и размытая, поэтому визуально очень сложно определить значение длины поверхностного слоя. «Размытость» границы, вероятно, связана с образованием продукта на поверхности не только за счет поверхностной реакции, но также за счет газовой диффузии $\mathrm{MoO}_{3}$. Поэтому погрешность в определении длины поверхностного слоя при больших временах увеличивается, и, используя лишь метод оптической микроскопии, невозможно совершенно точно определить, происходит ли полная остановка поверхностного процесса или лишь его резкое замедление. Для решения этой проблемы мы использовали растровую электронную микроскопию в комплексе с рентгеновским микроанализом.

Значение длины поверхностного слоя при двумерном распространении всегда ниже, чем значение $\ell_{s}$ при одномерном распространении при том же времени эксперимента. Причиной этого факта является то обстоятельство, что при радиальной диффузии происходит постоянное увеличение длины трехфазной границы диффузант/подложка/продукт, на которой и осуществляется непосредственное взаимодействие. В случае же одномерной диффузии длина этой границы постоянна.

То есть различие значений $\ell_{\mathrm{s}}$ для двух типов геометрий не является свидетельством различий скоростей поверхностных реакций, т. к. в этих двух случаях имеет место соответственно одно- и двумерная диффузия. Более корректной характеристикой скорости процесса, по нашему мнению, 
является относительная площадь, занимаемая поверхностным слоем (нормированная к площади контакта реагентов) $S_{\text {пов }} / S_{\text {конт }}$ Это можно пояснить следующими соображениями. Скорость поверхностной реакции определяется изменением количества продукта реакции, образующегося на поверхности, в единицу времени:

$$
W=\frac{d S_{\text {пов }}}{d \tau} .
$$

Количество вещества на поверхности пропорционально его объему: $n_{\text {пов }}$ $\sim V_{\text {sur }}$ В свою очередь, объем поверхностного слоя равен произведению его площади на толщину: $V_{\text {пов }}=S_{\text {пов }} \delta . \mathrm{B}$ первом приближении можно считать, что толщина поверхностного продукта $(\delta)$ величина постоянная, тогда количество продукта на поверхности пропорционально занимаемой им площади: $n_{\text {пов }} \sim S_{\text {пов }}$, откуда следует, что скорость реакции равна изменению площади продукта реакции, образующегося на поверхности, в единицу времени:

$$
W=\frac{d S_{\text {пов }}}{d \tau} .
$$

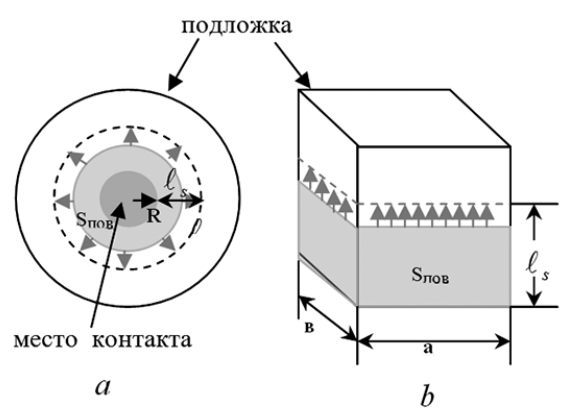

Рис. 4. Схема изменения площади поверхности продукта реакции: $a$ - радиальное (двумерное) распространение диффузанта; $\sigma$ - одномерное распространение диффузанта
В случае одномерной и двумерной диффузии площадь поверхностного слоя различным образом зависит от $\ell_{s}$. При радиальной диффузии площадь поверхностного слоя определяется выражением:

$$
S_{\text {пов }}=\pi\left(\left(r+\ell_{s}\right)^{2}-r^{2}\right)=\pi \ell_{s}\left(2 r+\ell_{s}\right),
$$

а при одномерной диффузии:

$$
S_{\text {пов }}=\ell_{\mathrm{s}} \cdot 2(a+b) \text {, }
$$

где $a$ и $b$ - длина и ширина брикета подложки, рис. 4.

Площадь поверхностного слоя зависит от площади контакта диффузанта и подложки, поэтому более корректно сравнивать не длину и даже не площадь, а относительную площадь поверхностного слоя (т. е. отношение площади поверхностного слоя к площади контакта реагентов). Площадь контакта реагентов равна $S_{\text {пов }}=a \cdot b$, где $a$ и $b$ - стороны основания подложки в случае одномерной диффузии и $S_{\text {конт }}=2 \pi r^{2}$, где $r$ - радиус диффузанта в случае радиальной диффузии.

Справедливость приведенных выше соображений показывает приведенная в качестве примера зависимость $S_{\text {пов }} / S_{\text {конт }}$ от времени для одномерной и двумерной диффузии в системе $\mathrm{Mn}_{2} \mathrm{O}_{3}-\mathrm{MoO}_{3}$, рис. 5 .

На рис. 5 видно, что кинетические зависимости $S_{\text {пов }} / S_{\text {конт }}$ для одномерного и двумерного распространения диффузанта близки.

Таким образом, относительная площадь поверхностного слоя является более корректной характеристикой скорости поверхностной реакции: при радиальном распространении диффузант рассредоточивается по поверхности подложки, образуя слой меньшей длины, но приблизительно такой же 
площади, что и при одномерной диффузии.

С целью определить режим взаимодействия, была проведена обработка кинетических кривых для случая одномерной диффузии по уравнению

$$
\ell^{n}=K \tau \text {. }
$$

Значения коэффициента n в уравнении (27) для исследованных систем приведены в табл. 3.

Таблица 3

Значения коэффициента $n$ в уравнении

$$
\ell^{n}=K \tau
$$

\begin{tabular}{c|c} 
Система & Коэффициент $n$ \\
\hline $\mathrm{CdO} / \mathrm{MoO}_{3}$ & $1,94 \pm 0,1$ \\
\hline $\mathrm{NiO} / \mathrm{WO}_{3}$ & $1,8 \pm 0,1$ \\
\hline $\mathrm{NiO} / \mathrm{MoO}_{3}$ & $1,9 \pm 0,1$ \\
\hline $\mathrm{Mn}_{2} \mathrm{O}_{3} / \mathrm{MoO}_{3}$ & $2 \pm 0,1$ \\
\hline $\mathrm{Pb}_{2} \mathrm{MoO}_{5} / \mathrm{MoO}_{3}$ & $2 \pm 0,1$
\end{tabular}

Коэффициент $n$ для всех систем близок к 2, следовательно, поверхностные реакции протекают в диффузионном режиме.

Исследование морфологии поверхностного слоя методом электронной микроскопии

Морфология подложки и слоя продукта, образованного в результате поверхностной реакционной диффузии (одномерной и двухмерной), была исследована методом электронной микроскопии, с целью прояснить следующие моменты. Во-первых, происходит ли остановка ПРД при одномерной диффузии или же диффузия по поверхности подложки не прекращается до тех пор, пока не истощится источник диффузии. Для этого, помимо РЭМ, проведен также рентгеновский микроанализ образцов.

Во-вторых, отличается ли морфология слоя продукта в месте контакта брикетов реагентов от морфологии поверхностного слоя.

РЭМ-исследования провели для шести систем: $\mathrm{CdO}-\mathrm{MoO}_{3}, \mathrm{CuO}-\mathrm{MoO}_{3}$, $\mathrm{PbO}-\mathrm{MoO}_{3}, \quad \mathrm{NiO}-\mathrm{MoO}_{3}, \quad \mathrm{NiO}-\mathrm{WO}_{3}$, $\mathrm{Mn}_{2} \mathrm{O}_{3}-\mathrm{MoO}_{3}$. В качестве примера приведены результаты РЭМ-исследований одномерной диффузии в системе CdO$\mathrm{MoO}_{3}$ и радиальной (двумерной) диффузии в системе $\mathrm{NiO}-\mathrm{MoO}_{3}$.

\section{Система $\mathrm{CdO}-\mathrm{MoO}_{3}$}

Образец для съемки получен методом контактного диффузионного отжига пары брикетов при одномерном распространении диффузанта в течение 167 ч при температуре $550{ }^{\circ} \mathrm{C}$. На-

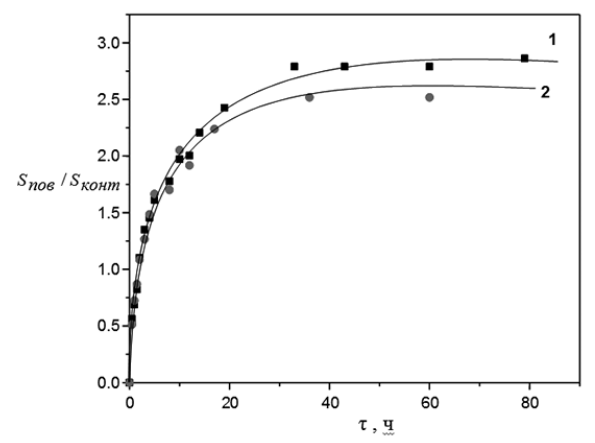

Рис. 5. Зависимость относительной площади поверхностного слоя от времени в системе $\mathrm{Mn}_{2} \mathrm{O}_{3}-\mathrm{MoO}_{3}: 1$ - одномерная, 2 - радиальная (двумерная) диффузия

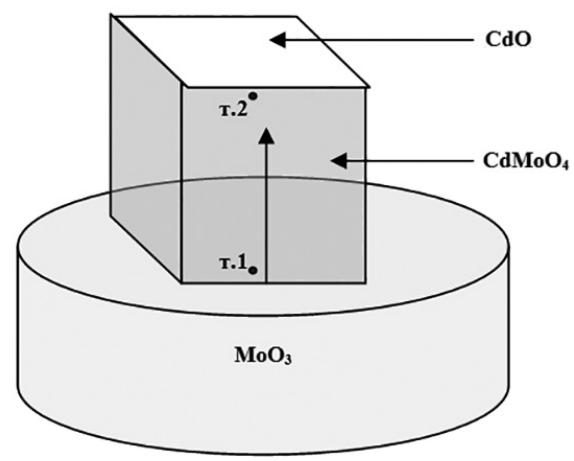

Рис. 6. Схема направления РЭМ-съемки образца 


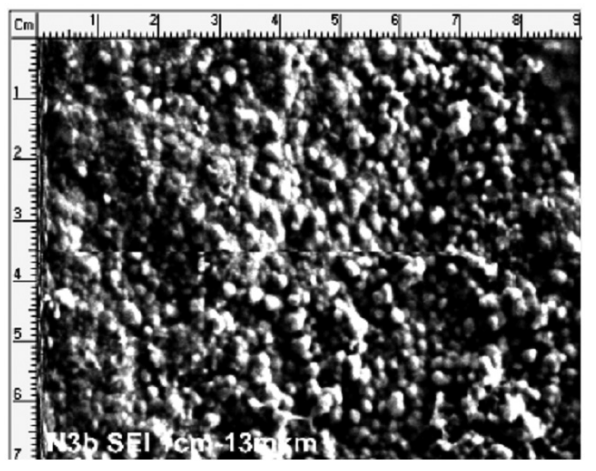

$a$

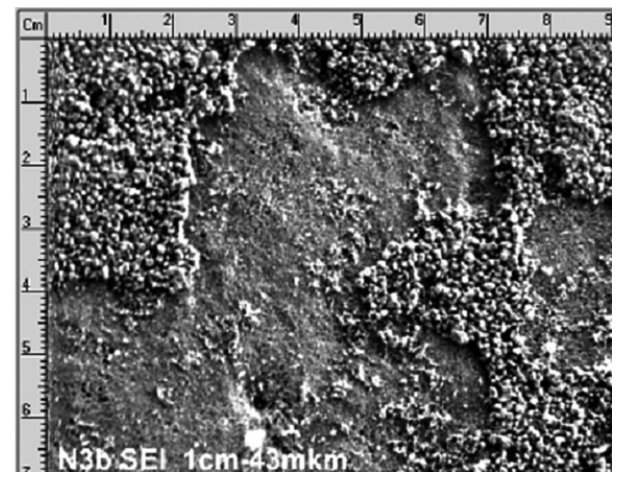

6

Рис. 7. РЭМ-изображение поверхностного слоя продукта $\mathrm{CdMoO}_{4}$ на подложке CdO: $a$ - в точке $1, \times 1000 ; 6$ - в точке $2, \times 300$ (рис. 6).

правление съемки показано стрелкой, от точки 1 к точке 2, рис. 6.

РЭМ-изображения продукта $\mathrm{CdMoO}_{4}$ в точке 1 и 2 (рис. 6) представлены на рис. 7, $a, 6$. Зерна продукта имеют средний размер 4-5 мкм (рис. $7, a)$. При удалении от места контакта, слой приобретает рыхлую структуру, местами отслаивается от подложки (рис. 7, б).

В месте отслоения продукта видны мелкие зерна подложки $\mathrm{CdO}$ размером 1-2 мкм.

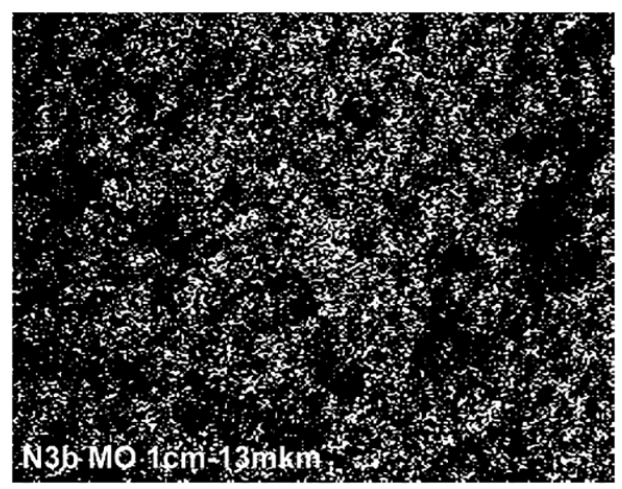

Рис. 8. Распределение рентгеновской плотности молибдена на поверхности подложки на расстоянии 4,5 см от места контакта
Продукт $\mathrm{CdMoO}_{4}$ полностью покрывает подложку $\mathrm{CdO}$, о чем свидетельствуют как РЭМ-изображения, а также данные рентгеновского микроанализа, которые показывают наличие молибдена на всей поверхности образца (рис. 8).

Таким образом, подтверждается сделанное ранее заключение о том, что при одномерном распространении диффузанта рост поверхностного слоя не прекращается при сколь угодно больших временах, пока не исчерпается источник диффузии.

Система $\mathrm{NiO}-\mathrm{MoO}_{3}$

Образец для съемки получен методом контактного диффузионного отжига пары брикетов при радиальном

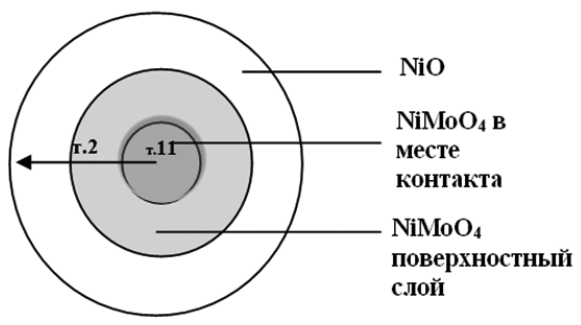

Рис. 9. Схема направления РЭМ-съемки образца 
распространении диффузанта в течение 4 ч при температуре $600{ }^{\circ} \mathrm{C}$. Направление съемки показано стрелкой (рис. 9).

Анализ РЭМ-изображений показывает, что размер зерен продукта $\mathrm{NiMoO}_{4}$ примерно одинаков во всех точках образца и составляет 1-2 мкм, рис. 10.

Как упоминалось ранее, методом оптической микроскопии невозможно с большой точностью определить длину поверхностного слоя. Для более точного ее определения методом рентгеновского микроанализа был снят концентрационный профиль [Mо] и [Ni], рис. 11.

На графике видно, что концентрация Мо в месте контакта брикетов диффузант/подложка велика и посто- янна по величине, затем, по мере удаления от места контакта, резко уменьшается. Это связано с радиальным распространением диффузанта по поверхности подложки, при котором длина реакционной границы постоянно растет, вследствие чего на переднем фронте диффузии образования сплошного слоя продукта не происходит; зерна продукта чередуются с зернами подложки, что физически соответствует убыванию концентрации молибдена по мере продвижения диффузанта. То место на образце, где фиксируется резкое убывание концентрации молибдена, совпадает с длиной поверхностного слоя, которая определена методом оптической микроскопии (1200 мкм).

Аналогичные результаты получены и для других исследованных систем.

\section{Выводы}

По результатам проделанной работы можно сделать следующие выводы:

1. Получено уравнение роста поверхностного слоя при радиальном распространении диффузанта, удовлетворительно описывающее кинетику поверхностного взаимодействия

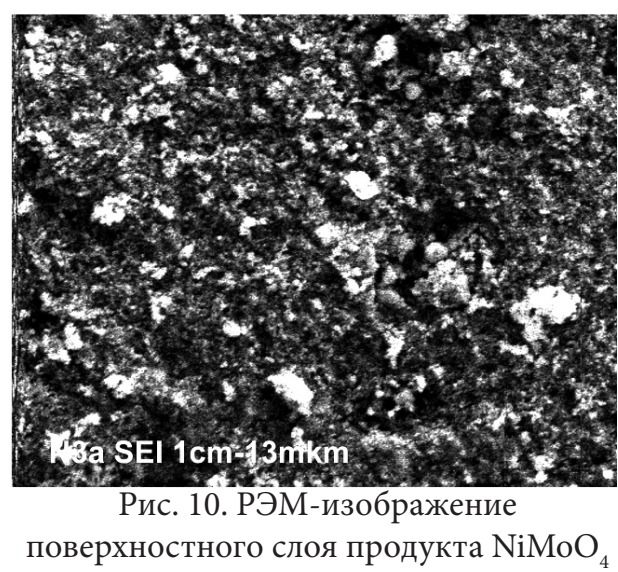

при временах меньших, чем время прекращения поверхностной реакции.

2. Исследована кинетика поверхностного взаимодействия в случае одномерного распространения диф-

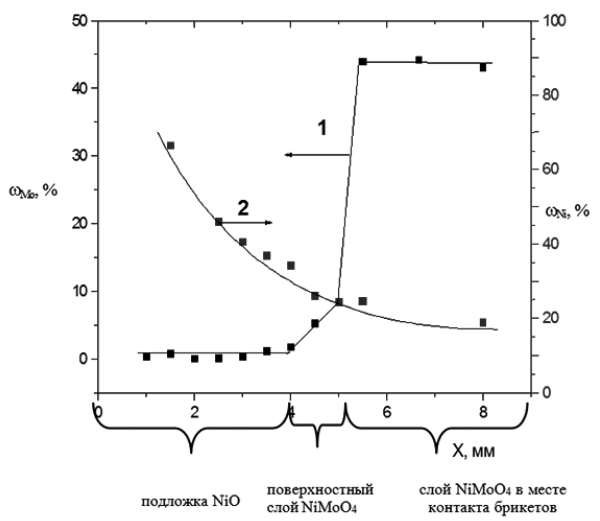

Рис. 11. Концентрационный профиль

(1) Mo; (2) Ni на образце $\mathrm{NiO}$ со слоем $\mathrm{NiMoO}_{4}$ (данные рентгеновского микроанализа) 
фузанта. Установлено, что поверхностные реакции протекают в диффузионном режим, и, в отличие от радиальной диффузии, поверхностное взаимодействие не прекращается даже при больших временах.

3. Установлено, что длина поверхностного слоя при одномерной диффузии больше, чем при радиальной, а относительная площадь, занимаемая поверхностным продуктом, практически одинакова в обоих случаях. По- следнее свидетельствует об одинаковой скорости поверхностной реакции при радиальном и одномерном распространении диффузанта.

4. Исследована морфология подложки, поверхностного слоя и морфология продукта, образующегося в месте контакта брикетов. Установлено, что поверхностный слой на переднем фронте реакционной диффузии не является сплошным, а состоит из отдельных зерен.

1. Neiman A. Ya., Guseva A. F. New Data on the Mechanism of Mass Transfer in SolidPhase Reactions: II. Chemical and Electrochemical Surface Phenomena. Kinetics and Catalysis. 1999; 40(1):38-49.

2. Neiman A. Ya., Guseva A. F., Trifonova M. V. Surface Reaction in the course of molibdates and tungstates formation. Solid State Ionics. 2001;141-142:321-329.

3. Neiman A. Ya., Guseva A. F., Trifonova M. V., Sukhankina I. V. Reactive Surface Diffusion durin Synthesis of Molybdates and Tungstates: The Role of Phase Constitution of Product. Russian Journal of Inorganic Chemistry. 2005;50:319-324.

4. Chebotin V. N., Perphiluev M. V. Electrochemistry of Solyd Electrolytes. Khimiya. Moscow, 1978. P. 67. (in Russian). 